\title{
The effect of seed scarification on the germination process and the growth of long bean (Vigna sinensis) sprout
}

\author{
Novita Ardiarini*, Jonathan Anugrah Lase, Yayat Hidayat, and Kisey Bina Habeahan \\ Assessment Institute for Agricultural Technology of North Maluku Province, Jl. Inpres Ubo-Ubo 241, \\ Ternate Selatan, Indonesia
}

\begin{abstract}
This study was aimed to determine the germination process of seeds with different scarification treatments. This research was conducted at the Laboratory of Animal Nutrition, Faculty of Animal Science, Universitas Gadjah Mada, July 2019. The treatment in this research were different scarification methods of the seeds by sanding (P1), wounding (P2), soaking in $\mathrm{H} 2 \mathrm{SO} 4(\mathrm{P} 3)$, soaking in warm water (P4), and baking at $55^{\circ} \mathrm{C}$ for 10 minutes (P5). Each treatment using 30 long bean seed that has been repeated for 3 times. Based on the five treatments, the seeds were planted in soil media and their growth observed for 14 days. The results showed that the seed growth for 14 days from the five treatments give an indication that the germination process and the first leaves grow out from long bean seeds was happen in treatment by oven $55^{\circ} \mathrm{C}(\mathrm{P} 5)$. Based on these results, it can be concluded that different scarification methods affected on the seed germination process. The fastest seed germination process to produce optimum growth in long bean plants was the scarification treatment by heating the seeds using an oven $55^{\circ} \mathrm{C}$ for 10 minutes (P5) before the seeds were planted.
\end{abstract}

\section{Introduction}

Long bean (Vigna Sinensis) by definition is a horticultural crop that contains a high of fiber. This plant has a great potential to be developed in Indonesia because it has large areas of adaptation and can be growth on the marginal lands, moreover it is relatively resistant to pests or diseases. The growth of a long bean seed could be maximizing if it is given a specific treatment to the seed. Germination process of seed can be observed with various methods of seed scarification. Scarification is a pretreatment of seeds that aims to break seed dormancy and accelerate the occurrence of uniform seed germination. Scarification is a way to provide a permeable condition of seeds through puncturing, burning, breaking, filing, and scratching with knives, needles, sandpaper, and other tools [1]. A permeable seed coat allows water and air to enter into the seeds, so the imbibition process can be occurred.

The seeds that are given the appropriate scarification method will produce a better imbibition process. Water and air will more quickly get into the seed because the seed coat is permeable. Water that enters to the seeds causes a metabolic process in the seeds and that

* Corresponding author: novita.ardiarini@mail.ugm.ac.id 
involves resulting a better germination [2]. Germination is a process metabolism, respiration, and hormones. Dry seeds absorb water to initiate the enzymatic breakdown of metabolite reserves during the germination process. Reserve metabolites such as protein, fats and oils during the germination process are metabolized to gain energy in the form of Adenosine Tri Phosphate (ATP) [3]. The result of this process is the formation of new cells and new tissues that initiates the growth of embryo into sprouts. A scarification method that is most appropriate for each type of seed will perform to break down the seed coat without damaging the embryo during the germination process. Through the most appropriate seed scarification method, it is hoped that long bean seeds will germinate and grow optimally.

\section{Methodology}

\subsection{Time and location}

This research was conducted at the Laboratory of Animal Nutrition, Faculty of Animal Science, Universitas Gadjah Mada, July 2019.

\subsection{Experimental design}

The treatment in this research were different scarification methods of the seeds by sanding (P1), wounding ( $\mathrm{P} 2)$, soaking in $\mathrm{H}_{2} \mathrm{SO}_{4}(\mathrm{P} 3)$, soaking in warm water (P4), and baking in oven at $55^{\circ} \mathrm{C}$ for 10 minutes (P5). In treatment 1 , seed were rubbed manually in a bottle which sandpaper was installed inside. In treatment 2 , seed were wound with knife. In treatment 3 , seed were soaking in sulfuric acid for 5 minutes with concentration of $80 \%$. In treatment 4 , seed were manually soaking in warm water with temperature of $40^{\circ} \mathrm{C}$ for 5 minutes. In treatment 5 , seed heated at $55^{\circ} \mathrm{C}$ for 10 minutes in an oven. Each treatment using 30 long bean seed that has been repeated for 3 times. Based on the five treatments, the seeds were planted in soil media and their growth observed for 14 days. The data collected included the height of the plant for 14 days. The data of plant height were analysed using descriptive quantitative analysis then the result of the research was described in Table 1 and Figure 1.

\section{Results and discussion}

The height of long bean is shown in Table 1 and the graph was presented in Figure 1. Based on the result, it seems that long bean seeds started germinating in four days after planting. The result showed that long bean seed in treatment sanding (P1) grown faster than long beans seed in treatment with wounding (P2), but the fastest growth was long bean seeds in the treatment with oven $55^{\circ} \mathrm{C}$ (P5). Meanwhile the long beans seed that soaked in warm water (P4) and soaked in $\mathrm{H}_{2} \mathrm{SO}_{4}(\mathrm{P} 3)$ did not grow at all. Scarification in seed pre-treatment is aimed to make the seed coat easier to be penetrated by the growing shoots. Long bean seeds that did not grow (P3 and P4) were due to the treatment process which made the seeds absorbed too much water.

The scarification treatment using sulfuric acid $\left(\mathrm{H}_{2} \mathrm{SO}_{4}\right)$ is a treatment method that is compatible for types of seeds having hard skin and are impermeable to germinate quickly. The acid concentration that usually used is $95 \%$ and the treatment can be done for 5 to 10 minutes [4]. Soaking with a chemical solution is expected to soften the seeds which have a hard-shell structure so the water and other substances that are useful for the germination process can enter to the seeds optimally [5].

The use of sulfuric acid in the germination treatment (P3) actually made long bean seeds could not grow at all because long bean seeds are not classified as seeds with very hard-shell 
structures. The sulfuric acid treatment damaged the structure of the long bean seeds so that they could not grow at all. Acid scarification might have removed the thick palisade layer of seed coat [6]. Effectiveness of the acid scarification may vary within the cultivars of same species, depending on their seed coat structures [7]. Each type of seed from various plants has a different level of seed coat hardness, then this affects the sensitivity of the seed coat to start an imbibition in the germination process [8].

Table 1. Height of long bean sprouts in various scarification methods

\begin{tabular}{|c|c|c|c|c|c|}
\hline \multirow{2}{*}{$\begin{array}{c}\text { Days } \\
\text { to }\end{array}$} & \multicolumn{5}{|c|}{ Height of long bean sprout (cm) } \\
\cline { 2 - 6 } & P1 & P2 & P3 & P4 & P5 \\
3 & - & - & - & - & - \\
4 & - & - & - & - & - \\
6 & 2,1 & 4 & - & - & 3 \\
8 & 4,3 & 7 & - & - & 7 \\
10 & 4,7 & 7 & - & - & 7 \\
12 & 5,4 & 8 & - & - & 7 \\
14 & 7 & 8 & - & - & 9 \\
& 9,6 & 9,4 & - & - & 10 \\
\hline
\end{tabular}

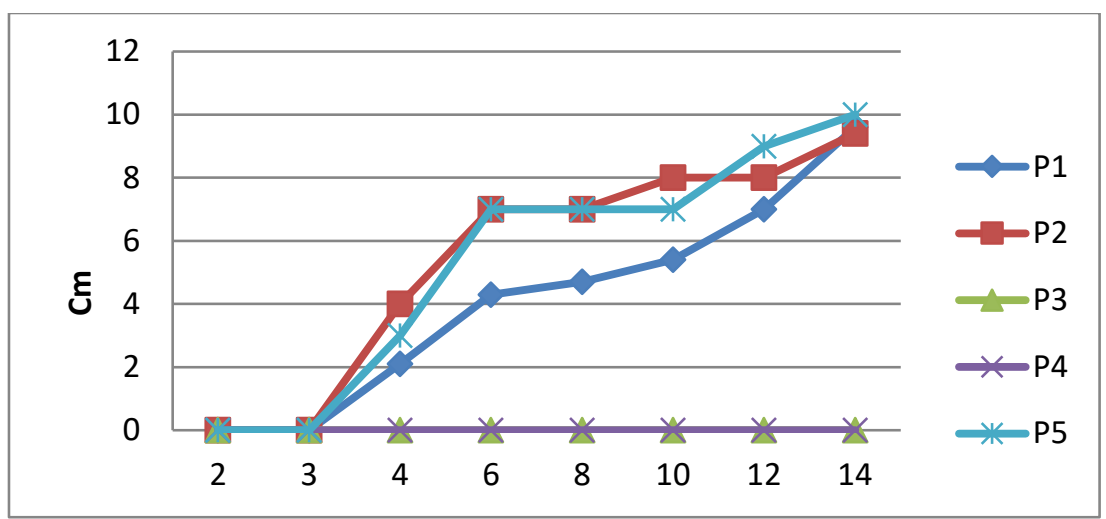

Fig. 1. Comparison of long bean sprout height with various methods of seed scarification.

The hard condition of the seed coat often causes the seeds to delay germination even though the seeds do not actually die. Seeds that have these characteristic must be given pretreatment to break the dormancy phase. Dormancy could be classifying on the basis of the causes and methods needed to break it [9]. One of them is physical dormancy, that happen where imbibition or water absorption is hindered by an impermeable seed layer. Methods of breaking dormancy naturally could be occurred due to temperature fluctuations, while the artificial dormancy breaking method could be done with mechanical scarification, the provision of hot water or soaking with chemicals. The method of breaking dormancy could increase seed germination percentage from 90 to $100 \%$. In this research, physical dormancy showed in treatment sanding (P1) where the seed were manually shaken in a bottle in which sandpaper was installed inside, and treatment wounding (P2) where the seed being wounding manually with knives. Treatment wounding give a better result in plant height than treatment sanding. This is because sandpaper destroy the long bean seed harder than wounded manually with knife. The effectiveness of mechanical scarification may vary depending on genus and species [10]. 
The height plant affected by light, temperature, humidity, and growth hormone [11]. Plants that did not grow can also be caused by the influence of fungal which causes plants to rot quickly and eventually died. Fungal pathogens that contaminate the seeds can reduce seed viability and decrease the seed germination [12]. Based on the observations in this study, it was found that the scarification method of soaking in warm water (P4) caused the seeds to not grow at all. This was because seeds absorbed water too much and affected the time of planting, the seed was rotten and there was no germination. Heat scarification methods using heat temperature effective on hard seed reduction and germination improvement if time and temperature that be used were appropriate $\left(40-50^{\circ} \mathrm{C}\right)$. Higher temperature effective on hard seed reduction compared to the lower temperatures, but negative impact was observed when temperature was higher than $80^{\circ} \mathrm{C}[13]$.

In the three other treatments of scarification method, the long bean seeds that were sanding (P1), wounding (P2), and baking in oven at $55^{\circ} \mathrm{C}$ could germinate and germination process occurred so the seed could grow from day 4 after treatment. Dry heat treatment did not give an adverse effect on the long bean seed sprouts and did not cause a damage to the elements of the seed [14]. Germination decline when temperature greater than $80^{\circ} \mathrm{C}$ and the number of dead seeds increased when temperatures were $90-93^{\circ} \mathrm{C}$ [15-17]. The germination process that occurred after the scarification treatment of long bean seeds was seed coat began to soften, prospective roots began to appear and grow, cell activity and enzymes presented in the seeds started to active so that air began to enter through the seed coat. At this stage the hypocotyl and cotyledon or the first leaves will begin to emerge. Reserve metabolites such as protein, fat and oils during the germination process had been metabolized to gain energy in the form of ATP, then it ready to be translocated to the plant growing points. The assimilation process to produce energy for the growth of new cells begins to appear and the formation of first leaves begins to appear in this phase [18].

Long bean seeds in this research (P1, P2, and P5) can be categorized as an epigeal germination, a germination process that occurs on the planting medium. The seed epicotyl then grows to release the first leaf, while the chip that contains the metabolite reserves will shrink along with the growth of new leaves and new roots. Effectiveness of scarification treatment may vary, but over treatment or longer time scarification may impose negative impact or injury the seed and causes the seed could not grow.

\section{Conclusions}

Different scarification methods affected on the seed germination process. Scarification methods such as heat, mechanical, and acid scarification are useful tools to soften hard seed, improve germination, and enhance seedling establishment. The most effective scarification technique that can be used for the growth of long bean seeds is heating using an oven at $55^{\circ} \mathrm{C}$ (P5). However, effectiveness of the methods varies depending on the duration of imposed treatments and species or cultivar that being used. Another factor that influences the process of seed germination among other varieties of seeds are hormone inhibiting germination (inhibitor), water supply, temperature, humidity, oxygen supply, sun light and growth medium.

\section{References}

1. Y.R. Wang, J. Hanson, and Y.W., Mariam. Journal of Seed Science and Technology, 39: 1. (2011)

2. Schmidt, L. PT Gramedia. Jakarta. Pp 530 (2000)

3. Acquaah, G.Pearson Education Inc. London (2005) 
4. M. Saleh, S.E. Adelina., E. Murniati, and T. Budiarti. Agroland Journal, 15: 3 (2008)

5. Tjitrosoepomo, G. Plant Morphology. Gadjah Mada University Press. (1999).

6. Pandrangi, S., M.W. Elwell, R.C. Anantheswaran and L.F. Laborde. J. Food Sci. 68: 613-617 (2003)

7. Taia, W.K. Pak. J. Biol. Sci., 7: 1287-1302 (2004)

8. Suyatmi ,. Hastuti, E. D and Darmanti, S. Journal of Laboratory Plant Structure and Function Biology (2011).

9. H.T.Hartman, D.E. Kester, F.T.Davies and R.L. Geneve. Prentice Hall. (1997)

10. Kimura, E. and M.A. Islam. Research Journal of Seed Science, 5: 38-50(2012)

11. D. Purnamasari, Effect of Soaking Concentration in Sulfuric Acid on Ki Hujan Seed Germination ( Samanea saman ). Department of Biology, Faculty of Science and Technology. State Islamic University of Malang (2009).

12. E.O. Sarihan, A. Ipek, K.M. Khawar, M. Atak, and B. Gurbuz. Journal Botany. 37: 4 (2005)

13. Rutar, R., M. Stjepanovic, S. Popovic, Z. Bukvic and D. Pacek. CIHEAM, 2: 137-139 (2001)

14. H.K. Yudha, A. S. Wirya, and IGN. Raka. Tropical Agroecotechnology E-Journal: 5 (2016)

15. Uzun, F. and I. Aydin. Asian J. Plant Sci., 3: 714-717 (2004)

16. Can, E., N. Celiktas, R. Hatipoglu, and S. Avci. Turk. J. Crops, 14: $72-78$ (2009)

17. Patane, C. and F. Gresta. J. Arid Environ., 67: 165-173 (2006)

18. Travlos, I.S. and G. Economou. Int. J. Bot., 2: 415-420 (2006) 